NARRATIVE MEDICINE

\title{
Deer in the Headlights
}

Tom Paluch, MD

Perm J 2017;21:17-014

E-pub: 06/26/2017

https://doi.org/10.7812/TPP/17-014

"But I'm only thirty-three years old," she says plaintively, as if some promise had been broken, some warranty had yet to reach its term. I have no easy response. Not quite speechless, I'm left with words that are of no value: words that can't possibly weaken the blow of the single, brutal word I'd just spoken. My first inclination is to duck behind the statistics that roll from my lips with practiced ease: they've served me well enough thus far. Easy to manipulate, the numbers lend a certain comfort or impose a certain gravitas depending on how I present them, on what I choose to emphasize.

“... Ninety percent survive ..." usually brings a brief halt to the tears, despite the fact that those very words mean that one-in-ten dies. I rarely mention the minority: it serves little purpose on a day like this, a day on which I've brought to someone's world a sentence that I haven't imposed, but merely transmitted.

The numbers matter not to her right now. She's only 33 years old. Only 33 and she has cancer. Her eyes are filled with tears and terror. She looks at me with those eyes I've seen a thousand times, searching mine for a hint, a clue, some subtle suggestion that it, that she, will be okay. I look at her as she sits in an openback gown, its silly blue and white pattern a garish contrast to the simple, but elegant, pinstriped suit she'd chosen to wear this morning. She'd probably chosen that suit as she had chosen her clothes each day: with an eye toward the effect they'd have on her appearance and on those who would see her. The effect was meant to be handsome and professional; the navy blue a stunning and contrasting complement to her flawless white skin and shoulderlength blonde hair. Now, as she sits on my examination table, her hands clutching the end of the cheap vinyl cushion in a grip that turns her knuckles white, her choice, her suit, is irrelevant. Her appearance is that of an innocent and vulnerable girl-child ripped from the predictability and security of her known world and thrown into mine, a world of frightening caprice, coarsened by nearly unintelligible jargon and terribly expensive technology. She doesn't know it now, but she'll never wear that suit again.

"Nobody in my family has breast cancer," she argues, as if that fact can somehow make benign the malignant cells that my biopsy needle removed from the lump in her right breast. I'll come to learn that she's an attorney, a bright and promising one at that; an attorney whose incisive intellect, diligence, and poise point to a future envied by her contemporaries. None would envy her at this moment.

"How sure are you that it IS cancerous?"

"Most breast cancers are sporadic," I respond quickly; then immediately, "Very sure," snuffing out any hope, desperate as it might be, that this was all a terrible mistake, and we all could go on as if nothing had happened. I begin my spiel, my canned speech explaining how "hopeful" breast cancer really is, using those damned statistics to show her how happy she should be that she has breast cancer, a cancer that claims only one-in-ten of its victims' lives over ten years, and not pancreatic cancer, which takes nearly every life it touches in less than three. I tell her of patients past, who are alive and well, leaving out the stories of those who were not fortunate enough to fall under the survivor curve in the graphs. She listens carefully, intently, hearing nothing.

She nods her head at the appropriate phrases, interrupting my practiced stoicism now and then to wipe a traitorous tear from her cheek. She barely flinches when I speak of operations yet to come, of the small but real chance that she may lose her breast, of the chemotherapy that will sicken her, steal her hair, and make her more fatigued than she can possibly imagine.

I look at her as I speak, and I hope my eyes won't betray methat the calm, even-tempered demeanor, the act I've cultivated for so many years, during so many of these conversations, will hold sway over my sadness: the deep, abiding grief that I feel at moments like this.

I hide in the safety of my lab coat, my hands shoved deep into its pockets. Its stiff white fabric offers armor-like security and authority. Yet somehow, it remains at once cold and stifling, like the corner of a deep cellar in the face of an oncoming storm. And like the family hiding from the tornado, I am at this moment impotent-little more than a spectator, doing what I know must be done but wondering just what good, if any, it will do.

She returns my gaze, eyes puddled with tears. I can smell the quiet terror beneath those tears. She's more concerned about the impact of this moment on her life than about her life itself. Immortality, that trait we quietly, insidiously learn as children, test as adolescents, accept as self-evident as young adults, then find so deceptively, patently false as we age, won't allow her to even consider the possibility of her death. She imagines the impact of this disease on her career and on her body, never giving thought to what it might do to the little girl that lives beneath the fine veneer of the woman she's become. I cannot and will not be the one who will frighten that little girl with the healthy dose of reality that has become my clinical experience.

For now, I'm the kindly doctor: reassuring, patriarchal, authoritative. In her eyes, I see the need for her to believe that I can do something - no, everything — to stand between her and her cancer. I don't have the heart to tell her that I'm just a man, a man with a special gift. It is a gift that lets me touch people's bodies in times of need. In that touch, on occasion, is a gift that's even greater: a chance to cure. Yet, as a condition of that gift, that 
unique and precious gift, comes a curse: a curse so oppressive and heartlessly savage that at times I wish to return the gift, to rescind the offer, to run away from this job, this profession, and never look back. The curse is simply that it is not up to me, that I can never, ever, choose whom it is who gets the cure.

And so I look at her, she with her frightened eyes and brave demeanor and wonder as I always wonder, "Will she be one of the lucky ones?"

"So what do you think my chances are?" she asks, eerily echoing my thoughts.

I stammer, then pause, the statistics poised on my tongue, ready to leap to the rescue: my rescue, not hers. Honesty prevails.

"I just don't know," I respond flatly. The profundity of those four words is not lost on her. Her eyes widen like those of a deer in the headlights on a lonely country road late at night, frozen by the oncoming, unknown terror, unable to run, waiting to see if this thing, this rushing menace will stop or sweep it away.

And then, forsaking technology, clinical acumen, surgical experience and expertise, abandoning science and logic, I practice the best medicine I know: I pull my hands from my pockets, place my arms around her shoulders, and hold her. Her sobs come now in huge heaves. Thankfully, there are no words.

At that moment, in the deepest recess of my soul, in that place where words don't dwell, but images live and flourish, I see that deer, the deer in the headlights, the one I saw moments ago. In this moment, this once, I imagine turning the wheel of that rushing machine, that determined, most certain engine of doom, and watching those soft, silent black eyes turn away knowingly, gratefully, and leap in a graceful, most vital leap, vanishing into the woods, finding its way to safety and survival.

I hold her until she somehow senses that image, until she, like that deer, chooses to fly to life.

\section{Disclosure Statement}

The author(s) have no conflicts of interest to disclosure.

How to Cite this Article

Paluch T. Deer in the headlights. Perm J 2017;21:17-014. DOI: https://doi.org/ 10.7812/TPP/17-014.

\section{Delicious Ambiguity}

I wanted a perfect ending. Now I've learned, the hard way, that some poems don't rhyme, and some stories don't have a clear beginning, middle, and end. Life is about not knowing, having to change, taking the moment and making the best of it, without knowing what's going to happen next.

_ Gilda Radner, 1946-1989, American comedian and actress 